\title{
Analysis of Students' Understanding of Concepts on Momentum and Impulse Material Using Research-Based Learning (RBL) Models
}

\author{
Nanda Safarati*and Rahma \\ Department of Physics Education, Universitas Almuslim \\ Jl. Almuslim, Bireuen, Aceh, Indonesia \\ *Email: nandasafarati@umuslim.ac.id
}

\begin{tabular}{|c|c|}
\hline Article Info & ABSTRACT \\
\hline $\begin{array}{l}\text { Article History } \\
\text { Received Mar 21, } 2020 \\
\text { Revised May 17, } 2020 \\
\text { Accepted June 18, } 2020 \\
\end{array}$ & $\begin{array}{l}\text { This study aims to analyze students' understanding of concepts in the material of } \\
\text { momentum and impulses using research-based learning (RBL) models. This type of } \\
\text { research is quantitative research with a descriptive approach. The population in this } \\
\text { study were students of class XI of SMA } 3 \text { Bireuen, the subjects in this study were }\end{array}$ \\
\hline $\begin{array}{l}\text { Keywords: } \\
\text { Concept understanding } \\
\text { Momentum and impulse } \\
\text { Research-Based Learning }\end{array}$ & $\begin{array}{l}\text { study indicate that } 30 \text { students in class } \mathrm{XI}^{2} .53 .3 \% \text { of students in the category } \\
\text { understood the concept, } 20 \% \text { students in the guessing category and } 26.7 \% \text { students in } \\
\text { the don't understand the category. This shows students will better understand the } \\
\text { concepts of momentum and impulses by using research-based learning models. }\end{array}$ \\
\hline $\begin{array}{l}\text { To cite this article: } \\
\text { N. Safarati and Rahm } \\
\text { Research-Based Lear }\end{array}$ & Models," Indones. Rev. Phys., v \\
\hline
\end{tabular}

\section{Introduction}

Education has an important role in a nation and is demanded to be relevant to the continued development of science and technology so that through education it is expected to be able to form people who have the skills to survive in the current globalization. According to Mudyaharjo [1] education is all learning experiences that take place in all environments and throughout life. One of the goals of education is to facilitate students to reach an understanding that can be expressed verbally, in the form of numbers and positive thinking frameworks [2].

Learning that requires understanding is learning to think at a high level because in it there is a concrete thinking process, namely the ability to think spiritually, think creatively, solve problems, and make decisions. According to Alatas [3], understanding is the result of teaching and learning that has indicators and each individual can explain or define a piece of information in his own words.

According to Deviyanti [4], physics learning aims so that students can understand scientific products (concepts, laws, principles, theories) based on scientific processes, so physics learning must actively involve students to interact in the learning process, physically or mentally and not just doing activities hand-on but also mind-on. The statement above is in line with the opinion [5], the most appropriate initial step to study physics is to understand the concept first. These concepts are arranged systematically, so that mastery of concepts is needed in each material.

Mastery of concepts is a basic ability that must be possessed by students to be able to understand concepts in accordance with the understanding of scientists [6]. This is reinforced by [7] which states that the purpose of learning is that students have good conceptual abilities so that students can develop the knowledge that students have previously had. BSPN [8] also states that mastery of good and correct concepts can improve students' intellectual abilities in solving problems related to natural phenomena.

Based on the results of research conducted by researchers at SMA Negeri 3 Bireuen, teachers in the learning process still use conventional methods and are teacher-centered. Also Besides, the demands of the institution and curriculum that requires the completeness of several some materials taught, so that the results take precedence over the learning process itself. The teacher tends to explain the material, give examples of questions and give practice questions that must be done by students, so students have accidentally been given an understanding that physics is a subject that deals only with numbers and calculations mathematically without explaining related concepts with material first.

As a result of the learning process carried out, students become passive and assume physics is a very frightening subject with a variety of formulas and numbers, so students do not understand the concepts of physics material they learn. Also besides, students are not able to connect between the material learned with a variety of knowledge and use in everyday life.

One of the materials students must master is momentum and impulses. Momentum and impulses are quantities related to the velocity and mass of an object, referring to the quantity of motion of an object and the mass of an object. The definition of momentum and impulse itself is interpreted as a quantity obtained from the multiplication between the magnitude of the velocity vector and the scalar mass of an object. 
Based on these problems, RBL is a learning model that helps students to learn effectively to find meaningful physics concepts. Trinasih [9] states that research-based learning provides opportunities for students to develop contextual concepts that emphasize the real situation with the stages that must be passed by discovering new things from the process of conducting research. The RBL learning model trains students to think critically and carry out research activities (conducting traces, hypotheses, collecting data, processing data and drawing conclusions).

\section{Theory \\ Concept Understanding}

Understanding concepts is a very important aspect and must be applied in learning because with the understanding of student concepts, the ability of students to understand learning material becomes faster and more developed. According to [10], understanding is how someone distinguishes, suspects, expands, concludes, gives examples, rewrites, and estimates. Rusman [11] states that understanding is the process of individuals who receive and understand information obtained from learning obtained through attention.

According to Soedjadi [12], concepts are abstract ideas that can be used to classify or clarify a group of objects. Students who master the concepts can identify and treat new questions that are more varied. Also besides, if the child understands a concept, then students can generalize an object in various other situations that are not used in learning situations [13]. Gusniawati [14] states that understanding concepts is an ability to find abstract ideas to classify objects that are usually expressed in terms and then poured into examples and not examples so that someone can understand a concept clearly.

Based on the opinion above, it can be concluded that understanding the concept is the process by which students discover, master and understand information obtained through thinking and acting in understanding each concept of an object.

\section{Research-Based Learning (RBL)}

The research-based learning model (RBL) is one of the new learning models that allow students to learn to build knowledge from research steps such as having to search for information, formulate hypotheses, collect data, analyze, make conclusions and prepare reports [15]. Research-based learning (RBL) is learning that builds student understanding, learning by developing prior knowledge, learning which is a process of social interaction and meaningful learning achieved through real experience. The learning process with this model requires students to be able to find, explore to face the problems faced, then test the truth of that knowledge [16].

The stages of the research-based learning (RBL) model according to [17] can be seen in Table 1.
Table 1. Sintax of the research-based learning model

\begin{tabular}{|c|c|c|}
\hline No & Phase & Activity \\
\hline 1 & $\begin{array}{l}\text { Formulating a general } \\
\text { Question }\end{array}$ & $\begin{array}{l}\text { Provide a formula in the } \\
\text { form of a topic or a } \\
\text { problem in the form of a } \\
\text { question }\end{array}$ \\
\hline 2 & $\begin{array}{l}\text { Overview of research- } \\
\text { literature }\end{array}$ & $\begin{array}{l}\text { Examining reference } \\
\text { material from various } \\
\text { literatures }\end{array}$ \\
\hline 3 & Defining the question & $\begin{array}{l}\text { Define question or } \\
\text { formulate a hypothesis }\end{array}$ \\
\hline 4 & $\begin{array}{l}\text { Planning } \\
\text { research activities, } \\
\text { clarifying methods/ } \\
\text { methodologies }\end{array}$ & $\begin{array}{l}\text { Explain, research } \\
\text { methods /methodology }\end{array}$ \\
\hline 5 & $\begin{array}{l}\text { Undertaking } \\
\text { investigation, analyzing } \\
\text { data }\end{array}$ & $\begin{array}{l}\text { Investigate by taking } \\
\text { data through observation } \\
\text { to school and to analyze }\end{array}$ \\
\hline 6 & $\begin{array}{l}\text { Interpretation and } \\
\text { consideration of results }\end{array}$ & $\begin{array}{l}\text { Analysis of the data } \\
\text { obtained is interpreted } \\
\text { and considered through } \\
\text { group discussion. }\end{array}$ \\
\hline 7 & $\begin{array}{l}\text { Report and presentation } \\
\text { of results }\end{array}$ & $\begin{array}{l}\text { Write it in report and } \\
\text { presenting }\end{array}$ \\
\hline
\end{tabular}

\section{Methodology}

This research uses quantitative research with a descriptive approach. Quantitative research methods are research methods that are based on the philosophy of positivism, used to examine a population or specific sample, collecting data using research instruments, analyzing quantitative/statistical data to test established hypotheses. Descriptive research is research conducted to determine the value of independent variables, either one or more variables (independent) without making comparisons or connecting with other variables [18]. So quantitative research with descriptive approach is research obtained from the results of population and sample analysis with the statistical method that you want to use. With the steps of formulating questions in the form of questions, studying literature, formulating hypotheses, conducting research methodologies, observing, analyzing and making reports.

According to [18], the population as a generalization area consisting of objects/subjects that have qualitative and certain characteristics determined by researchers to be studied and then drawn conclusions. The population in this study were all students of class XI IPA of Bireuen Public High School 3. Samples are part of that population [18]. The sample in this study were students of class XI IPA $_{2}$ consisting of 30 students.

The research instrument used was a physics concept understanding test instrument in the form of a multiplechoice test consisting of 10 multiple-choice questions. The reason for using multiple choice tests is because they are objective tests, and facilitate assessment. Material momentum and impulses to be tested that include the concept of momentum, impulse, conservation of momentum, and system momentum.

The percentage category of students' understanding level can be seen in Table 2 . 
Table 2. Percentage of Shiva's Understanding Level [19]

\begin{tabular}{ccc}
\hline No & Percentage & Category \\
\hline 1 & $\leq 30 \%$ & Low \\
2 & $30 \leq x \leq 60 \%$ & Medium \\
3 & $61-100 \%$ & High \\
\hline
\end{tabular}

Criteria for understanding students' concepts can be seen in Table 3.

Table 3. Student Answer Criteria [19]

\begin{tabular}{cccc}
\hline No & Question & Answer & Category \\
\hline 1 & $\begin{array}{c}\text { Multiple } \\
\text { Choice }\end{array}$ & Right & $\begin{array}{c}\text { Understand } \\
\text { the concept }\end{array}$ \\
2 & $\begin{array}{c}\text { Multiple } \\
\text { Choice }\end{array}$ & Right & $\begin{array}{c}\text { To guess } \\
\text { Multiple }\end{array}$ \\
Choice & Right & $\begin{array}{c}\text { Don't } \\
\text { understand } \\
\text { the concept }\end{array}$ \\
\hline
\end{tabular}

\section{Results and Discussion}

The results of data analysis that have been carried out at SMAN 3 Bireuen, on the material of momentum and impulse using research-based learning (RBL) learning models can be seen in Figure 1.

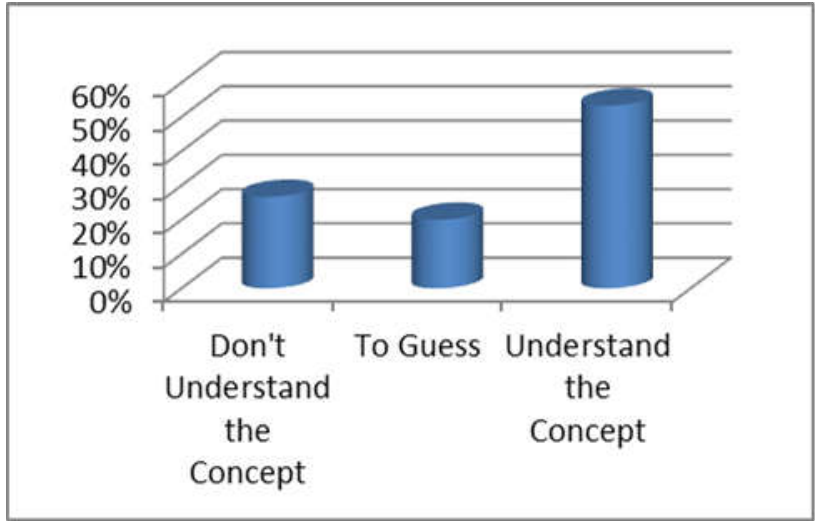

Figure 1. Percentage of students' understanding of concepts

Based on the results of data analysis shows that the understanding of students' concepts in the material of momentum and impulses using research-based learning (RBL) is in the medium category. From 30 students, the percentage of students understanding the concept category was $53.3 \%$, the percentage of students guessing the category was $20 \%$ and the percentage of students in the category, not understanding was $26.7 \%$.

Understanding the concept of sub-matter in the matter of momentum and impulse can be seen in Figure 2.

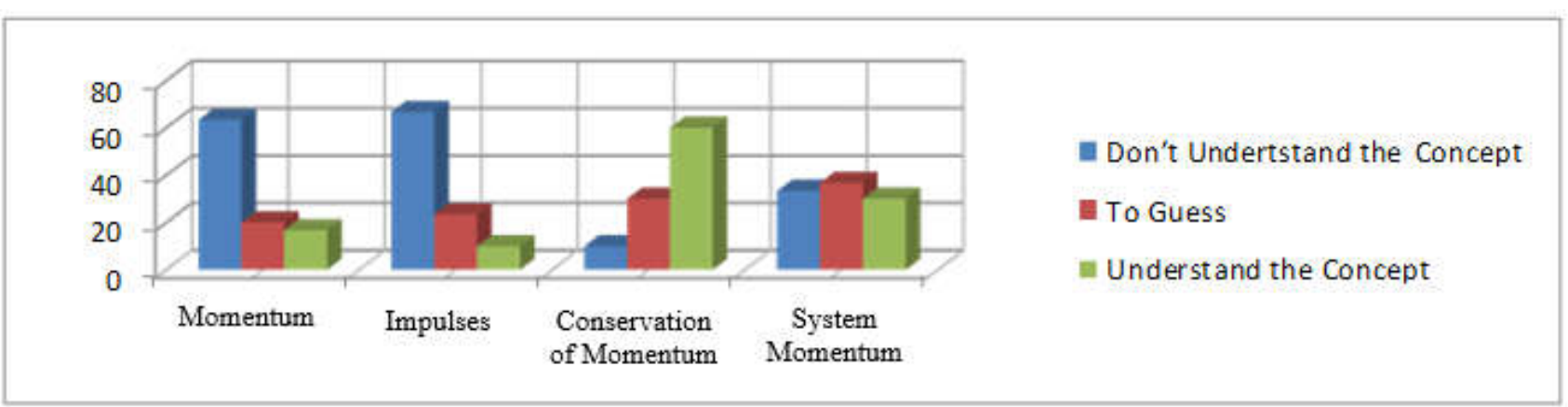

Figure 2. Percentage of students' understanding of the concept of Peru material

Based on the results of data analysis on students' understanding of the concept of sub-material, it can be seen that the submission of conservation of momentum is the most widely understood concept by students, with a percentage of $60 \%$, while for understanding the concept the least amount is contained in impulse material with a percentage of $10 \%$ With a total of 10 multiple choice questions.

The most guessed category is found in the momentum submitter with a percentage of $30 \%$ while the least guessed category is found in the momentum submitter with a percentage of $16.7 \%$.

The category of not understanding the concept is mostly found in impulse submersion with a percentage of $66.7 \%$ while the category of not understanding the concept is the least in the submission of conservation of momentum with a percentage of $10 \%$.

\section{Reference}

\section{Conclusion}

The conclusion of this study is based on the analysis of research data, namely the understanding of students' concepts becomes more visible when researchers use the RBL learning model. This can be seen from the percentage of the results of data analysis which shows that of the 30 students in class $\mathrm{XI}_{2}$, the percentage of students understanding the concept category was 53.3\%, the percentage of students guessing the category was $20 \%$ and the percentage of students in the category, not understanding was $26.7 \%$. This shows students will better understand the concept of momentum and impulse by using research-based learning (RBL) learning models. 
[1] S. Sagala, Konsep dan Makna Pembelajaran: Untuk Membantu Memecahkan Problematika Belajar dan Mengajar. Bandung: Alfabeta, 2003.

[2] H. Gardner, The Disciplined Mind: What All Students Should Understand. New York: Simon \& Schuster, 1999.

[3] F. Alatas, "Hubungan Pemahaman Konsep dengan Keterampilan Berpikir Kritis Melalui Model Pembelajaran Treffinger pada Mata Kuliah Fisika Dasar," Edusains UIN Syarif Hidayatullah, vol. 6, no. 1, pp. 8896, 2014.

[4] L. Deviyanti, "Pengembangan Panduan Praktikum Fisika Berbasis Research Based Learning Untuk Mengoptimalkan Domain Kognitif dan Psikomotorik Siswa di SMA Negeri 5 Purworejo." Program Studi Pendidikan Fisika FKIP Universitas Muhammadiyah Purworejo, 2016.

[5] P. R. Sasmita, "Penerapan Metode Inkuiri Terbimbing Menggunakan Media Kit Fisika: Upaya Meningkatkan Aktivitas dan Hasil Belajar Fisika Siswa," J. Ilm. Pendidik. Fis. Al-Biruni, vol. 6, no. 1, pp. 95-102, 2017.

[6] Y. T. B. Widodo, Cara Cerdas Mengerjakan Soal Fisika Mekanika Untuk SMA/MA: Brilliant Solution. Yogyakarta: Andi Offset, 2007.

[7] S. Rahmawati, S. Kusairi, and S. Sutopo, "Analisis Penguasaan Konsep Siswa yang Belajar Materi Momentum dan Impuls Berbasis Scientific Approach Disertai Formative Assessment Berbantuan Web," $J$. Pembelajaran Sains, vol. 3, no. 1, pp. 1-6, 2019.

[8] BSNP, "Permendiknas RI No. 22 Tahun 2006 Tentang Standar Isi untuk Satuan Pendidikan Dasar dan Menengah." Jakarta, 2016.

[9] A. B. Trisnasih, K. C. Suryandari, and Suhartono, "Peningkatan Keterampilan Proses dan Hasil Belajar IPA melalui Model Research Based Learning Siswa Kelas V SD," Kalam Cendekia, vol. 4, no. 4, pp. 1-7, 2016.

[10] L. W. Anderson and D. R. Krathwohl, A Taxonomy for Learning Teaching and Assessing: A Revision of Bloom's Taxonomy of Educational Objetives. New York: Longman, 2001.

[11] Rusman, Model-Model Pembelajaran. Jakarta: PT Raja Grafindo Persada, 2010.

[12] R. Soedjadi, "Kiat Pendidikan Matematika di Indonesia." Direktorat Jenderal Pendidikan Tinggi, Departemen Pendidikan Nasional, Jakarta, 2000.

[13] S. Nasution, Berbagai Pendekatan dalam Proses Belajar dan Mengajar. Jakarta: Bumi Aksara, 2005.

[14] M. Gusniwati, "Pengaruh Kecerdasan Emosional dan Minat Belajar Terhadap Penguasaan Konsep Matematika Siswa dalam SMAN di Kecamatan Kebun Jeruk," $J$. Form., vol. 5, no. 1, pp. 26-41, 2015.

[15] M. Salimi, T. S. Susiani, and R. Hidayah, "Research Based Leaning Sebagai Alternatif Model Pembelajaran di Lembaga Pendidikan Tenaga Kependidikan,” J. Pendidik. Sekol. Dasar, vol. 3, no. 1, pp. 1-9, 2017.

[16] S. M. Wardoyo, Pembelajaran Berbasis Riset. Jakarta: Akademia, 2013.

[17] P. Tremp, "Research-Based Teaching and Learning: A LERU Project." University of Zurich, Munich, 2010.

[18] Sugiyono, Metode Penelitian Pendidikan Pendekatan Kuantitatif, Kualitatif dan $R \& D$. Bandung: Alfabeta, 2013.

[19] W. P. Sari, E. Suyanto, and W. Suana, "Analisis Pemahaman Konsep Vektor pada Siswa Sekolah Menengah Atas," J. Ilm. Pendidik. Fis. Al-Biruni, vol. 6, no. 2, pp. 159-168, 2017. 